\title{
Revitalization of Islamic Education Teachers in the Development of Student Personality
}

\author{
Afiful Ikhwan ${ }^{1 *}$, Muhammad Farid ${ }^{2}$, Ali Rohmad ${ }^{3}$, Aldo Redho Syam ${ }^{1}$ \\ ${ }^{1}$ Universitas Muhammadiyah Ponorogo, Ponorogo, Indonesia \\ ${ }^{2}$ Institut Agama Islam Syarifuddin Lumajang, Lumajang, Indonesia \\ ${ }^{3}$ Institut Agama Islam Negeri Tulungagung, Tulungagung, Indonesia \\ *Corresponding author. Email: afifulikhwan@umpo.ac.id
}

\begin{abstract}
This research is motivated by a phenomenon of education in the present which is expected in the challenges of a more severe age where when a child enters elementary school in his soul there is a personality he brings from the family. If the child's educational lack of harmony due to family economic conditions, lack of awareness of parents, and also the influence of the environment will affect their personality, so the teacher's efforts are significant in carrying out the coaching. At the State Primary School (SDN) 1 Jepun Tulungagung. The teachers make every effort to build their students' personalities so that in the future, it can be a good example. This study describes the struggles and inhibiting factors and supporters of Islamic religious education teachers in the personality coaching of students in State Primary School 1 Jepun Tulungagung. Research findings that the implementation of Islamic Religious Education is good enough proved that the teacher had followed the procedures that are used in carrying out the teaching and learning process, while the personality of students has a lot of variables towards the good, so that it can be said enough, thus the efforts of the Islamic Religious Education teachers play an essential role in fostering personality of students.
\end{abstract}

Keywords: teacher, Islamic education, coaching and personality

\section{INTRODUCTION}

Education is a conscious and planned effort to create an atmosphere of learning and learning process so that learners are actively developing their potential so that they have spiritual power, self-control, personality, intelligence, noble character, and skills needed by him/her, society, nation and state [1].

The teacher is a very influential person in the learning process. Therefore, the teacher must bring his students to the goal to be achieved. Teachers must patronize students, teachers should be widely-held, and criteria for a teacher is to have the authority that can give the impression and influence [2].

In principle, teachers are only responsible for the implementation of the teaching and learning process. But also, he is expected to take responsibility for achieving national goals [3]. In this regard, efforts to educate and nurture young people need to be improved, even starting early on in the family (parents), school, or community [4]. Personality does not occur immediately, but it is formed through a long life process, therefore many factors that take part in the formation of the human personality [5]. Thus whether a person's character is good or bad, strong or weak is determined by the factors that affect the course of one's life. In this case, education plays an essential role in the formation of personality.

Thus, a religious teacher has a critical task that is participating in fostering the child's personality in addition to teaching religious knowledge to children, religious teachers must improve the private children who have been damaged, because of education in the family [6]. The religious teacher must realize that everything in himself is the element of cultivation for his students. In addition to education and teaching deliberately conducted by religious teachers for students, it is also very important and decisive also is the personality, attitude and way of life of the teacher itself, even how to dress, how to get along, talk and face any problems, which directly does not has to do with teaching, but in education or personal coaching the children, these things are very influential [7].

\section{LITERATURE REVIEW}

\subsection{Islamic Education Teacher}

According Muhibbinsyah teachers are people who work teaching [8]. An educator or teacher is someone who willfully influences others to achieve a higher level of perfection; the status of educator in this model can be carried by anyone, anywhere, and anytime [9]. Educators are also responsible for all activities that are in school and outside school. In a simple sense, the teacher is the one who gives knowledge to the students. The Law of the Republic of Indonesia Number 14 the Year 2005 on Teachers and Lecturers states that "Teachers are professional educators with the main task of educating, promoting, guiding, directing, training, assessing and evaluating learners in early childhood education formal education, basic education and secondary education" [10]. 
While Islamic education comes from three words, namely education, religion and Islam. Education is an effort to nurture and develop the personality of the spiritual and physical aspects also must take place gradually [11]. The Islamic word on Islamic education shows the colour of certain education, the Islamic coloured education that is normatively based on the Koran and as-Sunnah. According to Ahmad Tafsir, Islamic education is the guidance of a person to be a Muslim as much as possible [12]. Islamic Education is a conscious effort by educators to prepare learners to believe, understand and practice the teachings of Islam through the guidance, teaching or training that has been determined to achieve the goals set [13][14][15].

\subsection{The Role of Islamic Religious Education Teachers}

The role of teachers of Islamic Education and general teachers are the same, that is both trying to transfer the knowledge that he has to his students so that they understand more and know the more extensive experience. However, the role of Islamic religious education teacher in addition to trying to transfer knowledge (transfer of knowledge), he also must instil Islamic ethical values to their students so that they can relate between the teachings of religion and science [16].

Al-Ghazali advises Islamic educators to be eligible to become teachers of Islamic religious education: (1) Educators should regard their students as their own sons, so that their sense of responsibility is enormous and bestow their affection to the fullest, (2) the Educator (3) The teacher should be patient in giving advice to his or her students, (5) The educator must consider the ability of the ratio and mentality of his or her students (6) Educators must provide strong motivation to their students to love all the knowledge given, (7) Educators must offer subjects in the form of introduction of everyday experience for easy to understand and understand it to young students or under the age of age, and (8) Educators should set an example for his students [17].

\subsection{Personality Development}

Coaching is a process or activity that is carried out powerfully to obtain better results. While personality is a character which means behaviour possessed by a person so that it can be inherent and caused by environmental influences. Personality is often also referred to like a character that is a trait rather than a person, especially his character so that he is different from others [18][19]. Personality types: (1) sanguine type, namely popular and speaker, characteristics include: having a lot of strength, being passionate, having a passion for life, can make the environment happy and happy. However, this type also has weaknesses, among others: tend to be impulsive, act according to his emotions or desires. (2) phlegmatic types, namely peace and observer, characteristics include: tend to be calm, emotional turmoil does not appear, weaknesses include: there is a tendency to take it easy and do not want to be difficult. With this weakness, they are less willing to sacrifice for others and tend to be selfish. (3) melancholy type, namely thinker and perfect, characteristics include: obsessed with his best or most perfect work, understand the aesthetics of the beauty of life, his feelings are very strong and very sensitive, weaknesses include: very easily controlled by feelings and tend to be the feeling that underlies his daily life is a moody mood. (4) type of correspondent, that is strong and perpetrator, characteristics include: tend to be oriented towards work and tasks, have very high work discipline, are able to carry out tasks faithfully and are responsible for the duties they carry out, weaknesses include: underprivileged feeling the feelings of others, less able to develop compassion for people who are suffering, and feeling less playing. (5) certain type, which has characteristics such as: being able to express opinions, ideas, and ideas firmly, critically, but feeling soft so as not to hurt the feelings of others, because this certain type is the ideal type, so not many people find the weakness [20]. Therefore, an increase in students' conscious and planned cognitive moral considerations is intended to achieve this assertive type personality model [21].

\subsection{Management of Learners}

Facts in the field found the management system of students still using conventional ways and more emphasize the development of intelligence in a narrow sense and less attention to the development of creative talents learners [22]. Through Creativity, in addition to beneficial for selfdevelopment of students, is also a need for self-realization as one of the highest needs for humans [23].

The development of a good student is a balanced change of quality, both physically and mentally. There is no one aspect of development in students that are considered more important than others. Implementation of current education should be strived to provide special services to learners who have the creativity and also different giftedness for education can be directed to be better [24][25].

In education, students are a strategic focal point because it is the subject of teaching through a given teaching process. As a human being becomes an axiom that learners have their advantages and disadvantages, they are unique with all their potential and capacity in themselves, and this uniqueness can't be uniformed by one same rule between learners with one another, educators and school institutions should appreciate the differences that exist in themselves [26]. The uniqueness that occurs in the learner indeed raises an individual problem that must be known and solved so that the management of students (learners) in a unified framework is considered. Therefore, management of student management must be understood by people who work in school institutions, be it educators and educational staff who daily interact with students.

\section{RESEARCH METHOD}

This research uses interpretive paradigm through a qualitative approach, case study type. The analytical tool used is a qualitative analysis model of Miles and Huberman. 
This study describes the efforts and factors inhibiting and supporting teachers of Islamic religious education in the guidance of the personality of learners at the Primary School of 1 Tulungagung. Data collection techniques through interviews, observation and documentation, data analysis through stages: data presentation, data reduction, and conclusion drawing. Data checking was carried out through triangulation tests.

\section{RESULTS}

\subsection{Teacher Efforts in Student Personality Development}

The efforts of Islamic Religious Education teachers in the development of students' personality in the research location of Primary School 1 Jepun Tulungagung, East Java, Indonesia found are:

a. Through teaching: putting forward the teaching of religious education, because theological education is essential as the initial foundation to organize the student's personalities, as well as the support of coaching from the family, the community and the government.

b. Through habituation: familiarize, the students shake hands with teachers, is also a form of mutual respect between teachers and students that arise nuance of intimacy and compassion of teachers and students.

c. Through punishment: educating students to discipline and also behaving well so that penalty serves as a sense of responsibility what has been done.

\subsection{Inhibiting Factors and Teacher Supporters in Student Personality Development}

a. Supporting factors:

1) The existence of mosques in the school location, to assist in the implementation of religious activities so that in conducting practical activities do not interfere with other classes that are doing study in the classroom.

2) Extracurricular, such as scouts, tambourines (shalawat to the Prophet), recitations (reading alQur'an).

b. Inhibiting factors:

1) Lack of awareness of learners, there are still many students who are less aware of the importance of good personality or morality, so they ignore it due to lack of supervision from teachers and parents in controlling the association of children [27].

2) The family environment, the two majority parents, are busy working all day, even many become Indonesian Workers (TKI: meaning work abroad), so they do not get the attention of their parents who should be able to control the activities of his child daily.

\section{DISCUSSION}

\subsection{Master's Efforts}

Efforts made by teachers in fostering student personality in Primary School (SDN) Jepun 1 Tulungagung already in applied. This can be seen from the earnest efforts of the teacher to carry out the training, all of which are shown in a shot, namely: (1) through learning that enjoys, (2) through habituation which is to familiarize students to behave well, (3) through this punishment is carried out not just hate or dislike students, punish to educate students to turn into students who have a good personality.

Based on data obtained from the field shows that the efforts made by the teacher in fostering, the student's personality have been applied. The aim is made to increase the encouragement to students to be polite and well behaved. But it would be better if a teacher masters the psychological characteristics of students and know the background that causes them to have fewer good morals.

\subsection{Inhibiting and Supporting Factors}

Every activity to develop in the field of science is always influenced by the factors supporting and inhibiting. Likewise, in the efforts of teachers in guiding students' personalities at SDN 1 Jepun Tulungagung, there are several supporting and inhibiting factors experienced by teachers in the Public Elementary School (SDN) Jepun 1 Tulungagung. The supporting elements faced were the facilities and extracurricular activities, while the inhibiting factors were: lack of awareness of the students themselves and lack of attention to educating the morals of the parents of students due to working abroad (TKI).

\section{CONCLUSION}

The efforts made by religious teachers in the development of student personality in SDN 1 Jepun Tulungagung is through the first teaching, which emphasizes the teaching of religious education, so each lesson is given the values of religion, it is based on the religious education important as the initial foundation to organize the student's personality. The second through habituation is by doing routine habituation to bring sincerity in him when doing all the right actions. Third, this punishment is done not merely hate or dislike with students. Punish is to educate students to turn into students who have a good personality.

Supporting factors and obstacles in the development of student personality in the Primary School (SDN) 1 Jepun Tulungagung namely, the first supporting factor faced is the existence of supporting facilities and extracurricular that support the social psyche of students. Both of the inhibiting factors are the lack of awareness of the students and the family environment. 
[15] R. A. Suryadi, "Islamic Education in The Theological Perspective," Al-Hayat J. Islam. Educ., vol. 3, no. 1, pp. 29-37, 2019.

[1] W. Suwarno, Dasar-Dasar Ilmu Pendidikan Jogjakarta: Aruzz Media, 2009.

[2] Akhyak, Profil Pendidikan Sukses. Surabaya: Elkaf, 2005.

[3] A. Ikhwan, Pengembangan Kurikulum Pendidikan Agama Islam (PAI). Malang: Insan Cita Press dan STAIM Tulungagung, 2013.

[4] A. Ikhwan, "Introdoction to the Islamic Education Concepts (an Integral Paradigm Building Efforts)," in International Seminar on Islamic Law, Economic, Education and Science, 2014, p. 136.

[5] M. Suriadi Samsuri, Mursidin, "Character Education Based on Gender Justice in The Islamic Perspective," Al-Hayat J. Islam. Educ., vol. 2, no. 2, pp. 202-212, 2018.

[6] A. Ikhwan, Filsafat Pendidikan Islam: Memahami Prinsip Dasar. Yogyakarta: Diandra Kreatif, 2018.

[7] Z. Daradjat, Ilmu Jiwa Agama. Jakarta: PT. Bulan Terang, 2003.

[8] Muhibbinsyah, Psikologi Pendidikan. Bandung: Remaja Rodaskarya, 2010.

[9] F. Yasin, Dimensi-dimensi Pendidikan Islam. Malang: UIN Malang Press, 2008.

[10] Undang-Undang Nomor 20 Tahun 2003 Sistem Pendidikan Nasional dan Undang-Undang Nomor 14 Tahun 2005 tentang Guru dan Dosen. Jakarta, 2005, p. 35 .

[11] A. Ikhwan, "Metode Simulasi Pembelajaran dalam Perspektif Islam," Istawa J. Pendidik. Islam, vol. 2, no. 2, pp. 1-34, 2017.

[12] A. Tafsir, Metodik Khusus Pendidikan Agama Islam. Bandung: Remaja Rosdakarya, 1992.

[13] A. Majid, Perencanaan Pembelajaran. Bandung: PT. Remaja Rodaskarya, 2005.

[14] Mutholib, "Islamic Education Leadership Morality," Al-Hayat J. Islam. Educ., vol. 02, no. 01, pp. $1-7,2018$.
[16] A. Ikhwan, "Kajian Sosio-Historis Pendidikan Islam Indonesia Era Reformasi,” Edukasi J. Pendidik. Islam, vol. 5, no. 1, p. 17, 2017.

[17] H. Basri, Filsafat Pendidikan Islam, cet.ke-1. Bandung: Pustaka Setia, 2009.

[18] A. Ikhwan, "Integrasi Pendidikan Islami (NilaiNilai Islami dalam Pembelajaran)," Ta'allum J. Pendidik. Islam, vol. 2, no. 2, p. 184, 2014.

[19] D. N. Zahra, "Development of Islamic Education Curriculum Model Curriculum 2013 (K13)," Al-Hayat J. Islam. Educ., vol. 3, no. 1, pp. 38-52, 2019.

[20] A. Ikhwan, "Perguruan Tinggi Islam dan Integrasi Keilmuan Islam: Sebuah Realitas Menghadapi Tantangan Masa Depan," At-Tajdid J. Ilmu Tarb., vol. 5, no. 2, p. 160, 2016.

[21] Sjarkawi, Pembentukan Kepribadian Anak, cet. 2. Jakarta: PT. Bumi Aksara, 2008.

[22] A. Ikhwan, "Development Of Quality Management Islamic Education In Islamic Boarding School (Case Study Madrasah Aliyah Ash Sholihin)," Al-Hayat J. Islam. Educ., vol. 1, no. 1, p. 117, 2017.

[23] A. Ikhwan, "Manajemen Perencanaan Pendidikan Islam (Kajian Tematik Al-Qur'an dan Hadist)," Edukasi J. Pendidik. Islam, vol. 4, no. 1, p. 129, 2016.

[24] A. Ikhwan, "Leadership in Islamic Education; Study of Thematic Al-Qur'an and Al-Hadist," Ulul Albab J. Stud. Islam, vol. 17, no. 1, p. 3, 2016.

[25] Sulton, "Realitas Pendidikan Nilai Di Lingkungan Keluarga, Sekolah Dan Masyarakat,” Istawa J. Pendidik. Islam, vol. 1, no. 2, pp. 28-51, 2016.

[26] U. Sidiq and A. Ikhwan, "Local Government Policy Regarding Mandatory Students Diniyah Takmiliyah in Indramayu Regency," KARSA J. Soc. Islam. Cult., Jul. 2018.

[27] A. Ikhwan, "Management of Learning Assesment Using Curriculum 2013 (Case Study in Islamic Primary School (MI) Muhammadiyah 5 Wonoasri Ponorogo East Java - Indonesia)," MUADDIB Stud.

Kependidikan dan Keislam., vol. 08, no. 02, pp. 108$123,2018$. 